\title{
$\mathrm{TV}$ 홈쇼핑업체에서 개인환경 적합성이 조직 매력성, 몰입 및 직무 만족에 미치는 영향
}

\author{
이은진 · 홍병숙 \\ 중앙대학교 의류학과
}

\section{The Effect of Person-Environment Fit on Organization Attractiveness, Commitment, and Job Satisfaction in TV Home Shopping Companies}

\author{
Eun-Jin Lee and Byung-Sook Hong \\ Dept. of Clothing \& Textiles, Chung-Ang University; Seoul, Korea
}

\begin{abstract}
This study analyzes how the person-environment fit on organization attractiveness, commitment, and job satisfaction in TV home shopping companies. The survey was conducted from May 3 to 31 in 2010, and 350 responses were used in the data analysis. The statistical analysis methods were frequency analysis, factor analysis, reliability analysis, and multiple regression analysis. The results show that person-environment fit of TV home shopping companies is composed of person-job fit, person-supervisor fit, and person- organization fit. The person-job fit, person-supervisor fit, and personorganization fit of TV home shopping companies influence the organization attractiveness and commitment. The organization attractiveness and commitment affect the job satisfaction in TV home shopping companies.
\end{abstract}

Key words: TV home shopping companies, person-environment fit, organization attractiveness, organization commitment, job satisfaction

\begin{abstract}
1. 서
론

급변하는 현대사회에서 경제활동을 수행하는 개인들은 그들 을 둘러싸고 있는 조직의 환경을 고려하지 않고는 원활한 경제 활동을 수행하기 어려우며, 정보통신의 발달과 세계화로 글로 벌 무한경쟁 환경에 처해 있는 기업들은 생존경쟁에서 우위를 확보하기 위한 원동력으로 능력 있는 인재를 요구하고 있다. 이 에 따라 개인들은 조직에 적합한 능력을 지니기 위해 노력하고 있고, 기업 또한 유능한 인재의 확보 및 활용에 심혈을 기울이 고 있다(정진철 외, 2007; Verquer et al., 2003). 특히 TV 홈 쇼핑업체는 방송과 판매, 상담, 영업, 기획 및 전략 등의 복합 적인 업무형태를 이루며, 백화점, 대형할인점, 인터넷 쇼핑몰 등 과 경쟁하면서 계속적인 고객의 니즈 변화에 맞춰 각 업무가 유기적이고 신속하게 수행되어야 하기 때문에 직원들의 상호 협조와 교류가 무엇보다 중요하다. 뿐만 아니라 고객과의 커뮤 니케이션, 공급업체와의 협력 등을 통해 발전해야 하는 특성을 지니고 있어 빠르게 변화하는 환경에 대응할 수 있는 개인의
\end{abstract}

Corresponding author; Byung-Sook Hong Tel. +82-31-670-3281, Fax. +82-31-676-9932

E-mail: hongbs47@hanmail.net
능력이 요구되며, 개인과 환경간의 적합성 연구를 통해 개인의 능력을 최대한 이끌어낼 수 있는 방안을 수립해야 한다.

최근 들어 창의적인 아이디어와 능력을 지닌 인재를 유인하 고 유지하여 기업의 핵심역량과 성과를 높이는 것이 중요해지 면서 개인-환경 적합성은 조직분야에서 지속적으로 연구되고 있는 주제이며, 기존의 연구(최명옥, 유태용, 2005; 한계숙, 이 서구, 2009; Kristof-Brown et al., 2005)에서는 기업-환경 적 합성을 단일 요인으로 보지 않고 개인-직무 적합성, 개인-조직 적합성, 개인-상사 적합성 등으로 세분화하고 있다. 이중에서 개인-직무 적합성은 직무와 그 직무를 수행하는 개인 특성 간 의 일치 정도로 개인의 흥미나 관심사, 적성 및 능력 등과 직 무와의 일치정도, 직무를 통한 욕구나 목표의 충족 및 가치관 의 반영정도 등을 포함하고, 개인-조직 적합성은 개인의 가치 와 성격 등과 조직의 특성이 서로 상호작용을 하여 기업의 성 과에 영향을 미친다고 보는 것이다. 즉, 개인의 특성과 조직의 특성이 부합되면 조직의 성과가 향상되는 것을 전제로 하며, 개 인-상사 적합성은 개인과 상사와의 가치관이나 성격, 목표 등 이 일치하는 정도로서 일에 대해 상사와 비슷한 가치를 지니고 있을수록 개인의 성과가 높아질 수 있다(정진철 외, 2007; Kristof-Brown et al., 2005). 이러한 개인-환경 적합성에 대한 측정은 개인과 조직 환경과의 상호작용과정은 물론 조직에 대 
한 개인의 선택과 조직 내 개인의 동화작용을 보다 체계적으로 설명할 수 있다.

지금까지 수행된 개인-환경 적합성과 관련된 연구는 다차원 적인 개념에서 접근한 연구가 그다지 많지 않고, 개인과 조직 (박원우, 고수경, 2006; 정효선, 윤혜현, 2009; Van Vianen, 2000), 개인과 직무(신유형, 2008; 정인희 외, 2005; O'Reilly et al., 1991), 개인과 상사(성지영 외, 2008; Meglino et al., 1992) 등으로 구분하여 각각에 대한 적합성을 확인하는 연구가 주로 이루어져 왔다. 개인환경 적합성을 다차원적인 개념에서 접근한 Kristof-Brown et al.(2005)의 연구에서부터 이론이 구체 화되기 시작하였으며, 국내 연구(정진철 외, 2007; 최명옥, 유태 용, 2005; 한계숙, 이서구, 2009)에서는 개인환경 적합성을 세 분화하여 조직에 대한 관심이나 몰입을 유도하고, 직무에 대한 만족도를 높일 수 있는 요인으로 보고 있다. 이들 연구에서는 다양한 조직을 대상으로 개인환경 적합성을 측정하였으나, 공 기업과 대기업, 스포츠 조직 등을 실증 분석하고 있어 그 결과 를 유행과 변화에 민감한 소비자를 대상으로 상품을 판매하는 $\mathrm{TV}$ 홈쇼핑업체에 그대로 적용하기에는 어려움이 있다. 또한 정 진철 외(2007)와 Carless(2005)의 연구를 제외하고는 개인환경 적합성과 조직 매력성과의 영향력을 분석한 경우가 부족하여 이에 대한 연구가 요구된다.

한편, TV 홈쇼핑업체는 패션상품의 비중이 높은 유통업체로 서 상품의 기획과 판매, 영업, 방송 등의 다양한 업무영역으로 구성되어 있고, 이들 업무가 상호협력 하에 진행되기 때문에 개 인과 직무, 개인과 상사, 개인과 조직 간의 적합성이 개인의 태 도는 물론 기업의 성과에도 영향을 줄 수 있다. 그럼에도 불구 하고, 패션분야의 TV 홈쇼핑 관련 연구는 소비자의 구매행동 을 밝히는데 중점을 두고 있을 뿐 조직 관리의 관점에서 접근 한 연구는 거의 없는 실정이다. 지금과 같이 소비자 옥구와 시 장 환경이 급변하고, 홈쇼핑업체의 경쟁이 심화되면서 조직의 자체 역량과 조직을 둘러싸고 있는 외부 환경변화에 대응한 조 직 관리의 필요성이 대두되고 있는 시점에 개인환경 적합성 연 구는 TV 홈쇼핑업체의 인재 관리에 유용한 자료를 제공하고, 패션분야 조직연구의 기반이 될 수 있다. 따라서 본 연구는 TV 홈쇼핑업체의 패션사업부 직원을 대상으로 이들이 인지하는 개 인-환경 적합성을 측정하고, 개인-환경 적합성과 조직 매력성, 몰입 및 직무 만족 간의 영향관계를 분석함으로써 개인과 조직 환경의 상호작용 관점에서 조직에 대한 관심과 몰입도를 높이 고, 직무에 대한 만족도를 증가시킬 수 있는 방안을 수립하고 자 한다.

\section{2. 이론적 배경}

\section{1. 개인환경 적합성}

$\mathrm{TV}$ 홈쇼핑은 홈쇼핑업체가 제조업체나 도매업자로부터 제품 을 조달 받아 프로그램을 제작하여 케이블을 통해 지역 종합 유선 방송에 공급하고, 이를 시청한 소비자가 전화로 제품을 주
문하여 대금을 결제하면 소비자에게 제품이 배달되는 무점포 판매방식의 하나로서 홈쇼핑업체가 주체가 되어 소비자의 옥구 를 파악하고 적합한 상품구성과 적절한 촉진방법을 동원하여 판매를 한다(전타식, 2008). 이러한 특성으로 인하여 홈쇼핑업 체에서 개인의 직무는 단독으로 진행되는 것이 아니라 여러 부 서의 업무와 유기적으로 연결되어 있으며, 인터넷 쇼핑의 발달 로 방송만이 아니라 온라인 영역으로 사업을 확장하면서 부서 간의 상호관련성이 한층 복잡해지고 있다. 또한 $\mathrm{TV}$ 홈쇼핑업 체가 패션상품의 비중을 높이면서부터 패션사업부를 통해 상품 의 기획과 판매, 영업 및 방송 등의 업무를 진행하고 있고, 패 션사업부는 유행과 변화에 민감한 패션 소비자를 대상으로 하 여 상품을 판매하기 때문에 다른 분야에 비해 개인의 업무환경 이 더욱 전문적이면서 신속하게 이루어지고 있다. 이에 따라 개 인의 전문적인 능력이 요구될 뿐 아니라 개인의 성과가 매출과 직결되기 때문에 개인의 능력을 발휘할 수 있는 조직 환경과의 적합성과 인적 자원의 효율적인 관리가 기업 경영에서 중요한 과제가 되고 있다.

인간의 행동은 개인과 환경간의 끊임없는 상호작용에 의해 유발되는 것으로, 개인환경 적합성은 개인과 작업환경 간의 특 성이 유사하거나 일치하는 정도라고 정의할 수 있다(KristofBrown et al., 2005). 개인과 조직 환경과의 상호작용을 통해 개인의 태도나 행동을 예측하고자 하는 노력은 이미 오래전부 터 시도되어 왔고(성지영 외, 2008), 개인-환경 적합성 연구는 Lewin(1951)의 "행동은 개인의 특성과 환경의 특성이 결합되어 나타난다"는 주장과 Dawis and Lofquist(1984)의 직업적응이론 에 토대를 두고 있다. 직업적응이론(work adjustment theory)은 조직 구성원이 업무환경과 조화를 이루고 가치관이 적합성을 이루게 되면 직무수행의 만족도가 높아짐과 동시에 성과가 향 상될 수 있다는 점을 강조한다. Chatman(1989)은 개인환경 적 합성을 개인의 가치관과 조직 환경의 가치관이 조화를 이루는 정도라고 하였으며, 조직 환경이 개인의 옥구와 선호를 얼마나 충족시켜 주는가에 따라 개인-환경 적합성이 이루어진다.

조직분야의 연구에서는 개인환경 적합성의 관점을 보다 체 계화시키기 위해 다양한 관점에서 논리적 접근을 시도하였다. Kristof-Brown et al.(2005)은 개인-직무, 개인-조직, 개인-집단, 그리고 개인-상사의 4 가지로 개인-환경 적합성을 세분화하고, 적합성의 개념을 설명하는 논리적 근거로 유사성, 옥구-만족, 수요-능력의 조화에 중점을 두면서 상호적합성 관점, 보완적합 성 관점, 요구-공급 적합성과 요구-능력 적합성 관점으로 구분 하였다. 상호적합성 관점은 조직의 구성원들이 가치관의 유사 성을 보일 때 높은 적합성을 보인다는 것이고, 보완적합성은 개 인의 특성이 환경이 요구하는 점을 보완할 경우 적합성이 발생 한다는 것이며, 요구-공급 적합성은 개인이 요구하거나 선호하 는 점을 조직이 제공할 때 적합성이 발생한다는 것이다. 그리 고 요구-능력 적합성의 관점에서 조직이 요구하고 필요로 하는 점을 개인이 충족시키는 능력이 있을 때 개인과 조직은 적합성 이 이루어질 수 있다. 
개인이 일상적으로 접하게 되는 직무와 상사, 조직과 같은 환경에 대한 연구는 조직의 인적 관리를 통한 성과 항상의 측 면을 강조하며, 개인-직무 적합성(person-job fit)은 개인의 능력 과 직무 요구간의 적합성 혹은 개인의 요구와 직무 속성간의 적합성으로 정의된다(Edwards, 19991). 개인-조직 적합성 (person-organization fit)은 개인과 조직의 가치와 철학, 성격 등이 일치할 때 발생하는 것으로 조직이 개인에게 사회화 과정 의 기회를 제공하고, 이러한 기회를 개인이 선택하는 매커니즘 에 의해 개인과 조직의 적합성이 이루어진다(Chatman, 1989). 이는 Schneider(1987)의 ASA(attraction-selection-attrition) 모형 으로 설명할 수 있는데, 개인은 자신과 비슷한 조직에 매력을 느끼고 조직은 비슷한 사람을 선발하며, 조직과 비슷하지 않고 동화되지 않는 구성원은 결국 퇴출된다는 것이다. 그러므로 개 인과 조직간의 유사성이 낮은 경우에는 개인의 주요 태도변수, 예컨대, 만족도나 몰입, 이직의도 등에 부정적인 현상이 나타나 조직의 성과가 저하될 수 있다. 마지막으로 개인-상사 적합성 (person-supervisor fit)은 조직 안에서 개인과 상사와의 가치, 성격, 특성 및 목표 등의 적합성 정도를 나타내며, Bauer and Green(1996)에 의하면 상사와 부하의 성격 유사성은 서로 좋은 관계를 형성하는데 도움을 준다.

국내에서 개인-환경 적합성에 관한 연구를 살펴보면, 개인이 업무를 수행하는 과정에서 연계를 맺게 되는 직무나 상사, 조 직 등으로 세분화하고 각각의 개별적인 개념의 특징을 규명하 고 있다. 최명옥, 유태용(2005)은 개인-환경 적합성을 개인-직 무 적합성, 개인-상사 적합성, 개인-조직 적합성으로 분류하였 고, 정진철 외(2007)는 대기업과 공기업의 개인-업무환경 적합 성을 개인-조직, 개인-직무, 개인-상사 적합성으로 구분하였으 며, 김태희, 장경로(2007)는 스포츠센터 강사들의 개인환경 적 합성을 개인과 조직, 개인과 직무의 적합성 관점에서 규명하였 다. 또 성지영 외(2008)는 조직과 상사, 동료와의 관계에서 개 인-환경 적합성을 확인하였으며, 한계숙, 이서구(2009)에 따르 면 신용카드 및 보험회사 고객 콜센터 접점직원의 업무 성과에 영향을 미치는 개인-조직환경 적합성이 개인-직무, 개인-상사, 개인-동료, 개인-조직 적합성으로 나뉘어졌다.

이와 같은 조직환경 적합성은 급변하는 유통환경 속에서 패 션 상품을 취급하고 있는 TV 홈쇼핑업체에서도 나타날 수 있 는 다차원적인 개념이다. 따라서 본 연구는 선행연구를 토대로 하여 $\mathrm{TV}$ 홈쇼핑업체의 개인-환경 적합성을 개인과 직무, 개인 과 조직, 개인과 상사와의 적합성 측면에서 측정하고자 한다.

\section{2. 개인환경 적합성과 조직 매력성, 몰입 및 직무 만족과 의 관계}

개인과 환경과의 특성이 유사하거나 서로 잘 부합될 때 개 인은 물론 조직의 성과를 높일 수 있기 때문에 개인은 자신과 비슷한 특성을 지닌 조직을 선호하고, 조직은 해당 조직의 요 구에 맞는 인재를 선택한다. 이와 같이 개인과 조직의 상호작 용을 통한 개인-환경 적합성이 조직의 인적 자원 관리에서 중
요해짐에 따라 조직 분야에서는 개인과 업무환경과의 적합성에 관해 관심을 갖기 시작하였다. 개인이 업무를 수행하면서 상호 작용을 하는 직무나 조직, 상사 등과의 적합성을 분석한 연구에 의하면 높은 수준의 개인환경 적합성은 조직 매력성이나 조직 몰입, 직무 만족과 같은 개인적 태도와 관계가 있음이 밝혀지고 있다(Lauver \& Kristof-Brown, 2001). Harris and Mossholder (1996)는 개인환경 적합성이 조직 몰입이나 직무 만족을 높여 조직의 미래에 대해 낙관적인 관점을 가지게 한다고 주장하였 고, Saks and Ashforth(1997)에 따르면 개인과 환경과의 적합 성은 조직 몰입이나 조직 일체감, 조직을 떠나지 않으려는 결 정에 중요한 영향을 미친다. 즉, 개인과 환경과의 적합성이 높 을수록 조직에 대한 몰입도나 직무에서의 만족도가 높아진다고 할 수 있다.

개인-직무 적합성에 관한 연구에서 $\operatorname{Bretz}(1969)$ 는 개인이 중 요하다고 지각하는 직무특성과 실제 직무특성과의 적합이 직무 만족을 예측한다고 하였고, Lyons(1971)는 역할 명확성에서 개 인-직무 간 적합성이 직무 만족과 강한 정적 상관성을 보인다 는 것을 밝혔다. 개인-직무 적합성은 직무스트레스(O'Reilly et al., 1991)와 전직(Oleski \& Subich, 1996), 직업선택(Meir \& Melamed, 1986)에 영향을 미치고, 이직의도와 직무 만족 및 조직 몰입(정인희 외, 2005; Lauver \& Kristof-Brown, 2001) 과 관련이 있다. O'Reilly et al.(1991)은 개인-직무 적합성에 대한 지각이 높은 사람이 그렇지 않은 사람보다 더욱 적극적인 직무 태도를 가질 뿐 아니라 스트레스 관련 증후군이 더 적다 고 하였으며, Lauver and Kristof-Brown(2001)은 개인이 가진 기술과 직무가 요구하는 능력 간의 적합성으로 개인의 과업수 행 수준을 설명하였다. 정인희 외(2005)에 의하면 패션 판매원 의 직무 적합성은 직무 만족과 정적인 상관관계를 보였고, 김 태희, 장경로(2007)는 스포츠센터 강사들의 개인-직무 적합성이 직업변경의도의 부적 영향요인이라고 하였으며, 신유형(2008) 은 개인-직무 적합성이 조직시민행동과 팀 효능감의 예측 변수 라고 하였다.

개인-조직 적합성은 조직 구성원을 유지하고, 조직에 대한 구 성원의 몰입을 높여 기업의 경쟁우위를 가져오게 하는 주요 수 단으로 인식되고 있다(김경수, 김공수, 1998). 기존의 연구(정진 철 외, 2007; 정효선, 윤혜현, 2009; Van Vianen, 2000)에서는 개인과 조직 간의 적합성이 조직 매력성이나 몰입, 직무 만족 등에 영향을 미친다고 하였으며, 개인의 가치와 조직의 가치가 일치할수록 직원들은 조직에 더욱 몰입하고 만족한다(O'Reilly et al., 1991). Schneider et al.(1995)은 개인과 조직의 높은 동질성이 협력과 조화를 증진시켜 조직에 긍정적인 영향을 준 다고 하였고, Sims and Keon(1997)은 개인이 선호하는 윤리적 작업분위기와 실제의 분위기가 일치할 때 개인의 만족이 더욱 커진다고 하였다. 또한 양혁승, 정영철(2002)은 개인의 가치와 조 직 가치와의 적합성이 태도에 미치는 영향력을 검증하였으며, 박 원우, 고수경(2006)은 개인-조직 적합성과 조직 몰입, 직무 만족 과 같은 개인 태도변수 간의 관계에서 프로세스 갈등이 매개효 
과를 가진다고 언급하였다.

개인-상사 적합성에 관해서는 비슷한 선호도를 가진 사람과 일하거나 일에 대해 상사와 비슷한 가치를 지니고 있을 경우에 개인의 직무 만족이나 조직 몰입이 증가한다는 연구(Meglino et al., 1992)가 있다. Kemelgor(1982)의 따르면 직무 만족이 높은 부하가 직무 만족이 낮은 부하보다 상사와 더 유사한 가 치구조를 가지는 경향이 있었고, 박양규(1999)는 상사와 부하 간 리더십 행동특성의 적합성이 조직유효성에 미치는 효과를 입증하였으며, 최수일, 이은진(2009)은 팀장의 지적자극 리더십 과 개인적 배려가 직무 만족에 영향을 미친다고 하였다. 성지 영 외(2008)는 개인-상사 적합성이 개인의 성과에 영향을 미친 다고 주장하였으나, 개인-상사 간의 성격이 일치하지 않는 것 이 더 바람직하다고 제시한 연구(유태용, 현희정, 2003; Smith, 2002)도 있어 개인-상사 적합성 연구는 연구대상에 따라 일관 되지 않은 결과를 보이고 있다.

개인환경 적합성과 조직 매력성, 몰입 및 직무 만족과의 관 계를 분석한 선행연구를 살펴보면, Smidts et al.(2001)은 조직 에 대한 정보를 자주 접할수록 구성원들은 조직에 더 매력을 갖게 된다고 하였고, Carless(2005)는 개인과 조직, 개인과 직무 적합성이 조직 매력성에 영향을 미친다고 하였다. 정진철 외 (2007)는 개인환경 적합성, 즉, 개인과 조직, 직무, 상사와의 적 합성이 조직 매력성 지각을 통해 선제적 행동에 미치는 영향력 을 검증하였는데, 여기서 조직 매력성은 조직에 대해 호감을 갖 는 정도로서 조직에 대한 관심 정도나 동일시, 우호적 평가 및 조직 정체성 형성에 중요한 역할을 한다(Turban \& Greening, 1996). 성지영 외(2008)의 연구에서 개인-환경 적합성은 개인의 성과에 영향을 미치는 요인이었고, 한계숙, 이서구(2009)는 개 인환경 적합성과 성과간의 구조적 관계를 분석하였으며, 허명 숙, 천면중(2009)은 개인환경 적합성과 정보시스템 수용요인이 조직 구성원의 성과에 미치는 영향에 관하여 연구하였다. 또한 조직 몰입과 직무 만족은 개인의 작업태도 변수 중의 하나로서, 이들 변수 간에는 정적인 관련성(오인수 외, 2007)이 있어 조직 에 대해 몰입할수록 직무에 대한 만족도가 더 높아진다고 할 수 있다.

\section{3. 연구방법 및 절차}

\section{1. 연구문제}

본 연구는 TV 홈쇼핑업체에서 개인-환경 적합성과 조직 매 력성, 몰입 및 직무 만족 간의 영향관계를 알아보기 위하여 다 음과 같이 연구문제를 설정하였다.

연구문제 1. TV 홈쇼핑업체에서 개인환경 적합성의 구성요 인을 알아본다.

연구문제 2. TV 홈쇼핑업체에서 개인환경 적합성이 조직 매 력성 및 몰입에 미치는 영향을 알아본다.

연구문제 3. TV 홈쇼핑업체에서 조직 매력성 및 몰입이 직
무 만족에 미치는 영향을 알아본다.

\section{2. 측정도구}

본 연구는 측정도구로 설문지를 사용하였고, 설문지는 $\mathrm{TV}$ 홈쇼핑업체에서 개인환경 적합성에 관한 문항, 조직 매력성, 몰입 및 직무 만족에 관한 문항, 인구통계적 특성에 관한 문항 으로 구성하였다. 개인환경 적합성에 관해서는 김태희, 장경로 (2007), 최명옥, 유태용(2005), 한계숙, 이서구(2009), KristofBrown et al.(2005) 등의 연구와 예비조사 결과를 참조하여 개 인-직무, 개인-조직, 개인-상사 적합성에 관한 총 18 문항을 5 점 Likert 척도로 측정하였다. 조직 매력성은 정진철 외(2007), Carless(2005) 등의 연구와 예비조사 결과를 기초로 하여 현 직 장에 대한 관심이나 호감도, 업무에 대한 애착 정도 등에 관한 총 6 문항을 5 점 Likert 척도로 측정하였고, 조직 몰입은 박원우, 고수경(2006), 오인수 외(2007), O'Reilly et al.(1991) 등의 연구 와 예비조사 결과를 토대로 하여 조직에 몰두하는 정도에 관한 총 6 문항을 5 점 Likert 척도로 측정하였다. 직무 만족은 박원우, 고수경(2006), 오인수 외(2007), 정인희 외(2005) 등의 연구와 예 비조사 결과를 참조하여 자신이 수행하는 업무에 보람을 느끼 거나 적성에 맞고 만족한다는 내용을 포함한 총 5 문항을 5 점 Likert 척도로 측정하였으며, 인구통계적 특성으로 성별, 연령, 결혼여부, 학력, 연봉, 근무업체 및 근무부서에 관한 총 7 문항 을 명목척도로 측정하였다.

\section{3. 자료수집 및 분석}

본 연구는 자료 수집을 위하여 서울 소재의 TV 홈쇼핑업체 중에서 매출과 인지도, 패션상품의 비중이 높은 GS홈쇼핑, $\mathrm{CJ}$ 오쇼핑, 현대홈쇼핑의 패션사업부에 근무하는 직원을 대상으로 예비조사와 본조사를 시행하였다. 예비조사는 2010년 4월 19 일에서 4월 26일 사이에 80 명을 대상으로 실시하였고, 예비조 사 결과를 참조하여 설문지를 수정 및 보완하였다. 본 조사는 업체별 비율을 고려하여 2010년 5월 3일부터 5월 31일 사이에 임의 표집 방식에 의해 실시하였으며, 결측치가 없는 총 350 부 를 자료 분석에 사용하였다. 수집된 자료는 SPSS Ver. 17.0을 이용하여 빈도분석, 요인분석, 신뢰성 분석, 다중회귀분석 등을 실시하였다.

연구대상자의 인구통계적 특성을 살펴보면, 남성이 185 명 $(52.9 \%)$, 여성이 165 명 $(47.1 \%)$ 이었고, 연령은 20 대가 90 명 (25.7\%), 30대가 225명(64.3\%)으로 대부분이 20대, 30대였으며, 기혼자가 183 명(52.3\%)으로 미혼자 167 명(47.7\%)보다 많았다. 대학교 졸업 이상이 309 명 $(88.3 \%)$ 으로 학력수준이 비교적 높은 편이었으며, 연봉은 4,000 만원 미만이 176 명(50.3\%), 4,000 만원 $\sim 5,000$ 만원 미만이 102 명(29.1\%), 5,000만원 이상이 72 명 (20.6\%)이었다. 또한 근무업체는 GS홈쇼핑이 119명(34.0\%), CJ 오쇼핑이 117 명 $(33.4 \%)$, 현대홈쇼핑이 114 명(32.6\%)이었고, 근 무부서는 MD 113명(32.3\%), PD 89명(25.4\%), 기획 및 마케팅 
Table 1. 개인-환경 적합성에 대한 타당성 및 신뢰성 분석 결과

\begin{tabular}{|c|c|c|c|c|c|}
\hline 요인명 & 문항 & 요인 부하량 & 고유값 & 누적분산(\%) & 신뢰계수 \\
\hline \multirow{6}{*}{ 개인-직무 적합성 } & 내 직무는 평소 내가 가진 흥미나 관심사와 잘 맞는다 & .804 & \multirow{6}{*}{4.15} & \multirow{6}{*}{23.06} & \multirow{6}{*}{.903} \\
\hline & 내 직무는 내 적성과 잘 맞는 편이다 & .789 & & & \\
\hline & 내 직무는 내가 가진 능력을 발휘하기에 적합하다 & .775 & & & \\
\hline & 내 직무는 나의 욕구를 충족시켜 준다 & .762 & & & \\
\hline & 내 직무는 내가 추구하는 목표를 이루기에 적합하다 & .756 & & & \\
\hline & 내 직무는 평소 내가 추구하는 가치관을 잘 반영하고 있다 & .712 & & & \\
\hline \multirow{6}{*}{ 개인-상사 적합성 } & 상사와 나는 행동하는 방식이 비슷하다 & .825 & \multirow{6}{*}{4.12} & \multirow{6}{*}{45.94} & \multirow{6}{*}{.907} \\
\hline & 상사와 나는 가치관이 비슷한 편이다 & .823 & & & \\
\hline & 상사는 전반적으로 나와 비슷한 성격을 가지고 있다 & .821 & & & \\
\hline & 상사와 나는 일처리 방식이 비슷하다 & .801 & & & \\
\hline & 상사와 나는 서로 공통되는 특성이나 유사한 관심사가 많다 & .732 & & & \\
\hline & 상사와 나는 직무에서 추구하는 목표가 비슷하다 & .713 & & & \\
\hline \multirow{6}{*}{ 개인-조직 적합성 } & 우리 회사가 추구하는 가치는 평소 내가 추구하는 가치와 잘 맞는다 & .810 & \multirow{6}{*}{3.87} & \multirow{6}{*}{67.42} & \multirow{6}{*}{.887} \\
\hline & 우리 회사의 경영 철학은 나의 평소 생각이나 철학과 일치한다 & .795 & & & \\
\hline & 우리 회사의 운영방식은 내가 추구하는 가치와 잘 맞는다 & .748 & & & \\
\hline & 우리 회사의 이미지가 바로 내 이미지인 것 같다 & .732 & & & \\
\hline & 우리 회사와 나는 서로 공통되는 부분이 많다 & .715 & & & \\
\hline & 우리 회사의 특성은 내가 가진 성격적 특성과 비슷한 점이 있다 & .702 & & & \\
\hline
\end{tabular}

67명(19.1\%), 행정 및 일반사무 50명(14.3\%) 등의 순이었다.

\section{4. 연구결과 및 논의}

\section{1. 타당성 및 신뢰성분석}

본 연구는 측정 변수의 타당성 및 신뢰성을 확인하기 위하 여 요인분석과 신뢰성분석을 실시하였다. 요인분석에서는 요인 값 0.5 이상, 고유치 1.0 이상인 요인을 추출하였고, 신뢰성 분석 의 경우 신뢰계수 0.6 이상이면 최소한의 조건을 갖추었다고 볼 수 있다.

\subsection{1. 개인-환경 적합성}

$\mathrm{TV}$ 홈쇼핑업체에서 개인-환경 적합성에 대한 총 18 문항을 요인 분석한 결과, Table 1 과 같이 고유치 1.0 이상인 3 개의 요 인이 추출되었다. 요인 1 은 개인의 직무가 자신의 흥미나 관심 사 및 적성에 잘 맞고, 자신의 능력을 발휘하기에 적합하며, 직 무를 통해 개인의 욕구를 충족시키거나 자신이 추구하는 목표 를 이루기에 적합하다는 항목으로 구성되어 있어 '개인-직무 적합성'이라 하였다. 요인 2 는 개인의 행동하는 방식이나 가치 관, 성격 및 일처리 방식이 상사와 비슷하고, 자신과 상사가 서 로 공통되는 특성이나 유사한 관심사가 많으며, 직무에서 추구 하는 목표가 비슷하다고 여기는 내용을 포함하고 있어 '개인상사 적합성’이라고 하였다. 요인 3은 회사가 추구하는 가치나 경영 철학이 자신의 가치나 생각과 잘 맞고, 회사의 운영방식 이나 이미지가 자신에게 적합하며, 자신과 회사가 공통되는 부
분이 많다고 인식하는 항목으로 구성되어 있어 '개인-조직 적 합성’이라 명명하였다.

이들 요인의 총 변량은 $67.42 \%$ 였고, 가장 높은 설명력을 보 인 요인은 '개인-직무 적합성'이었으며, 요인분석 과정에서 모 든 문항이 요인값 0.5 이상을 보여 제거된 문항은 없었다. 또한 신뢰성 분석 결과 크론바하 알파(Cronbach's alpha) 계수가 0.85 이상으로 나타나 문항의 신뢰성이 높았다. 본 연구에서 TV 홈쇼핑업체의 개인-환경 적합성이 개인-직무, 개인-상사, 개인조직 적합성으로 분류된 것은 정진철 외(2007), 최명옥, 유태용 (2005), Kristof-Brown et al.(2005) 등의 연구와 일관된 것이 며, TV 홈쇼핑업체 직원의 경우 자신과 조직 환경과의 적합성 에 대한 인식 정도가 비교적 높다고 할 수 있다.

\subsection{2. 조직 매력성, 몰입 및 직무 만족}

조직 매력성, 몰입 및 직무 만족에 대해서는 각각 요인분석 과 신뢰성분석을 실시하였다. 그 결과 Table 2에서처럼 조직 매 력성에 관해서는 고유치 1.0 이상인 1 개의 요인이 도출되었고, 직장에 대한 관심과 호감, 우호적 평가 등에 관한 항목으로 구 성되었으며, 요인의 총 변량은 $62.86 \%$ 였다. 조직 몰입에 관해 서는 고유치 1.0 이상인 1 개의 요인이 도출되었고, 자신의 직장 에 몰입하고 있는 정도에 관한 내용으로 구성되었으며, 요인의 총 변량은 $58.51 \%$ 였다. 직무 만족에 관해서도 고유치 1.0 이상 인 1 개의 요인이 도출되었고, 현재 자신의 업무에 대한 보람과 만족 등에 관한 항목을 포함하였으며, 요인의 총 변량은 $67.22 \%$ 였다. 또한 요인분석 과정에서 모든 문항의 요인값이 
Table 2. 조직 매력성, 몰입 및 직무 만족에 대한 타당성 및 신뢰성 분석 결과

\begin{tabular}{|c|c|c|c|c|c|}
\hline 요인명 & 문항 & 요인부하량 & 고유치 & 분산(\%) & 신뢰 계수 \\
\hline \multirow{6}{*}{ 조직매력성 } & 나는 우리 회사에 대해 관심이 많은 편이다 & .815 & \multirow{6}{*}{3.77} & \multirow{6}{*}{62.86} & \multirow{6}{*}{.882} \\
\hline & 내가 가진 기술이나 지식이 우리 회사에 꼭 필요한 것이어서 회사가 매력적으로 느껴진다 & .802 & & & \\
\hline & 나는 우리 회사에서 수행하는 업무가 마음에 들어 애착을 가지고 있다 & .795 & & & \\
\hline & 우리 회사가 나에게 일할 수 있는 기회를 주어서 고맙게 생각한다 & .786 & & & \\
\hline & 나는 우리 회사가 일하기 좋은 직장이라고 생각한다 & .783 & & & \\
\hline & 내가 가진 능력을 회사에서 인정해 주고 있어 우리 회사에 대해 호감을 느낀다 & .775 & & & \\
\hline \multirow{6}{*}{ 조직몰입 } & 나의 개인적 목표는 현재 직장에서의 직무와 연관되어 있다 & .818 & \multirow{6}{*}{3.51} & \multirow{6}{*}{58.51} & \multirow{6}{*}{.855} \\
\hline & 나는 내 직장에 몰두하고 있으며, 관심사의 대부분이 나의 직장에서부터 나온다 & .817 & & & \\
\hline & 내 인생의 가장 중요한 것들은 내 직장과 관련되어있다 & .795 & & & \\
\hline & 나는 직장에서 내가 맡은 직무를 하면서 즐거움과 행복을 느낀다 & .793 & & & \\
\hline & 나는 여가시간보다 직장에서의 업무시간이 더 즐겁다 & .711 & & & \\
\hline & 내 시간의 대부분을 나의 직장에 할애하는 편이다 & .638 & & & \\
\hline \multirow{5}{*}{ 직무만족 } & 현재 내가 수행하고 있는 업무에 보람을 느낀다 & .876 & \multirow{5}{*}{3.36} & \multirow{5}{*}{67.22} & \multirow{5}{*}{.855} \\
\hline & 현재 내가 맡은 직무는 내 적성에 맞는 편이다 & .841 & & & \\
\hline & 현재 내가 맡은 업무량과 업무내용에 만족한다 & .810 & & & \\
\hline & 현재 내가 하고 있는 직무를 수행하면서 나의 능력을 상당부분 발휘하고 있다 & .805 & & & \\
\hline & 시간이 어떻게 지나가는지도 모를 정도로 현재 직무에 재미와 만족을 느끼고 있다 & .763 & & & \\
\hline
\end{tabular}

0.5 이상을 보여 제거된 문항은 없었으며, 신뢰성 분석 결과 조 직 매력성 0.882 , 조직 몰입 0.855 , 직무 만족 0.855 로 신뢰 계수가 0.85 이상으로 나타나 문항의 신뢰성이 높은 편이었다.

\section{2. 개인환경 적합성이 조직 매력성 및 몰입에 미치는 영향}

본 연구는 $\mathrm{TV}$ 홈쇼핑업체에서 개인-환경 적합성이 조직 매 력성 및 몰입에 미치는 영향을 알아보기 위하여 동시투입에 의 한 다중회귀분석을 실시하였고, 다중회귀분석에 있어서 변수들 간의 투입타당성을 확인하기 위해 다중공선성을 진단한 결과 $\mathrm{VIF}$ 값이 1.000 으로서 다중공선성의 문제는 없는 것으로 나타 났다. 먼저 조직 매력성을 종속변수로 하고, 개인환경 적합성 의 요인인 개인-직무 적합성, 개인-상사 적합성 및 개인-조직 적합성을 독립변수로 하여 다중회귀분석을 실시한 결과, Table 3 에서와 같이 개인-환경 적합성의 모든 요인이 조직 매력성에 통계적으로 유의한 영향을 주고 있었다. 구체적으로, 개인-직무 적합성이 $\beta=0.575, \mathrm{t}=14.995, \mathrm{p}<.001$ 에서, 개인-상사 적합성이 $\beta=0.245, \mathrm{t}=6.392, \mathrm{p}<.001$ 에서, 개인-조직 적합성이 $\beta=0.316$, $\mathrm{t}=8.250, \mathrm{p}<.001$ 에서 영항을 미치고 있었고, 이중에서도 개인직무 적합성의 영향력이 가장 높았으며, 조직 매력성에 대한 개 인-환경 적합성의 전체 설명력 $\left(\mathrm{R}^{2}\right)$ 은 $49.4 \%$ 였다. 다시 말해, $\mathrm{TV}$ 홈쇼핑업체에서 개인의 직무가 자신의 흥미나 관심, 적성 에 적합하고, 개인의 행동하는 방식이나 가치관, 성격 및 일처 리 방식이 상사와 비슷하며, 회사가 추구하는 가치나 경영 철 학이 자신의 가치나 생각과 잘 맞는다고 인식할수록 회사에 대 해 더 많은 관심을 가지고 회사에서의 업무에 애착이 있을 뿐 아니라 회사에서 일하는 것을 고맙게 여길 정도로 호감을 지니 고 있었다.
이러한 결과는 개인과 직무, 개인과 조직 적합성이 조직매력 성에 영향을 미친다고 한 Carless(2005), 정진철 외(2007) 등의 연구와 일관된 결과를 나타낸 것이다. 그러나 정진철 외(2007) 의 연구에서는 본 연구와 달리 개인-상사 적합성이 조직매력성 에 미치는 영향력이 없는 것으로 나타났는데, 이는 연구대상의 차이에서 기인한 것으로 판단된다. 따라서 $\mathrm{TV}$ 홈쇼핑업체에서 는 개인과 직무, 개인과 조직 적합성은 물론 개인과 상사 적합 성도 조직의 매력성을 높이는 영향요소라 할 수 있으므로 회사 에 대한 관심이나 호감도를 높이기 위해서는 개인과 직무, 조 직 및 상사와의 적합도를 고려해서 인력을 관리해야 할 것이다.

다음으로 조직 몰입을 종속변수로 하고, 개인환경 적합성의 요인인 개인-직무 적합성, 개인-상사 적합성 및 개인-조직 적합 성을 독립변수로 하여 다중회귀분석을 실시한 결과, 개인-환경 적합성의 모든 요인이 조직 몰입에 통계적으로 유의한 영향을 미치는 것으로 나타났다. 구체적으로 살펴보면, 개인-직무 적합 성이 $\beta=0.552, \mathrm{t}=13.981, \mathrm{p}<.001$ 에서, 개인-상사 적합성이 $\beta=0.201, \mathrm{t}=5.088, \mathrm{p}<.001$ 에서, 개인-조직 적합성이 $\beta=0.339$, $\mathrm{t}=8.585, \mathrm{p}<.001$ 에서 영항을 미치고 있었고, 이중에서도 개인직무 적합성의 영향력이 가장 높았으며, 조직 몰입에 대한 개 인환경 적합성의 전체 설명력 $\left(\mathrm{R}^{2}\right)$ 은 $46.0 \%$ 였다. 즉, 직무를 통 해 개인의 옥구를 충족시키거나 자신이 추구하는 목표를 이루 며, 자신과 상사가 서로 공통되는 특성이나 유사한 관심사가 많 음은 물론 회사의 운영방식이나 이미지가 자신에게 적합하다고 인식할수록 자신의 직장에 더욱 몰두하고 직장생활에서 즐거움 과 행복을 느끼고 있었다. 그러므로 직장생활을 하면서 개인이 자신의 직무나 상사, 조직과의 적합성을 인식하도록 만드는 것 이 조직에 몰입할 수 있는 방법이라 할 수 있으며, 이 결과는 
Table 3. 개인환경 적합성과 조직 매력성 및 몰입에 관한 회귀분석 결과

\begin{tabular}{|c|c|c|c|c|c|}
\hline 종속변수 & 독립변수 & $\beta$ & $\mathrm{t}$ & $\mathrm{F}$ & $\overline{\mathrm{R}^{2}}$ \\
\hline \multirow{3}{*}{ 조직 매력성 } & 개인-직무 적합성 & .575 & $14.995^{* * *}$ & \multirow{3}{*}{$111.261 * * *$} & \multirow{3}{*}{.494} \\
\hline & 개인-상사 적합성 & .245 & $6.392 * * *$ & & \\
\hline & 개인-조직 적합성 & .316 & $8.250 * * *$ & & \\
\hline \multirow{3}{*}{ 조직 몰입 } & 개인-직무 적합성 & .552 & $13.981 * * *$ & \multirow{3}{*}{$98.354 * * * *$} & \multirow{3}{*}{.460} \\
\hline & 개인-상사 적합성 & .201 & $5.088 * * *$ & & \\
\hline & 개인-조직 적합성 & .339 & $8.585^{* * *}$ & & \\
\hline
\end{tabular}

$* * * p<.001$

Table 4. 조직 매력성과 몰입 및 직무 만족에 관한 회귀분석 결과

\begin{tabular}{cccccc}
\hline 종속변수 & 독립변수 & $\beta$ & $\mathrm{t}$ & $\mathrm{F}$ & $\mathrm{R}^{2}$ \\
\hline \multirow{2}{*}{ 직무만족 } & 조직 매력성 & .584 & $14.632^{* * * *}$ & \multirow{2}{*}{$254.404^{* * *}$} & .595 \\
& 조직 몰입 & .285 & $7.148^{* * *}$ & & \\
\hline$* * * p<.001$ & & & &
\end{tabular}

개인과 직무간의 적합성이 조직 몰입에 영향을 준다고 한 Kristof-Brown et al.(2005)의 연구, 개인과 조직 간의 적합성이 조직 몰입의 영향요인이라고 밝힌 박원우, 고수경(2006)의 연 구, 개인과 상사 간에 비슷한 가치를 지닐수록 조직 몰입이 증 가한다고 한 Meglino et al.(1992)의 연구와 비슷한 맥락에서 이해할 수 있다.

\section{3. 조직 매력성 및 몰입이 직무 만족에 미치는 영향}

조직 매력성 및 몰입이 직무 만족에 미치는 영향을 알아보 기 위하여 직무 만족을 종속변수로 하고, 조직 매력성 및 몰입 을 독립변수로 하여 다중회귀분석을 실시하였으며, 다중회귀분 석에 있어서 다중공선성을 진단한 결과 VIF값이 1.363으로서 다중공선성의 문제는 없는 것으로 나타났다. 또한 Table 4에서 처럼 조직 매력성은 $\beta=0.584, \mathrm{t}=14.632, \mathrm{p}<.001$ 에서, 조직 몰 입은 $\beta=0.285, \mathrm{t}=7.148, \mathrm{p}<.001$ 에서 직무 만족에 영향을 미치 고 있었고, 조직 매력성의 영향력이 조직 몰입보다 더 높았으 며, 직무 만족에 대한 조직 매력성 및 몰입의 전체 설명력 $\left(\mathrm{R}^{2}\right)$ 은 $59.5 \%$ 였다. 이는 자신의 회사에 대해 관심이 많고, 자신의 능력을 회사에서 인정해 주거나 수행하는 업무가 마음에 들어 회사에 대해 호감과 애착을 느낄수록 현재 수행하는 업무에 더 보람을 느끼고 업무량 및 업무내용에 더욱 만족한다는 것을 의 미한다. 따라서 $\mathrm{TV}$ 홈쇼핑업체에서 직원들의 직무 만족을 유 도하기 위해서는 직장에 대한 관심과 애착을 이끌거나 몰입할 수 있는 요소를 제공해야 할 것이다.

\section{5. 결론 및 제언}

본 연구는 TV 홈쇼핑업체의 패션사업부 직원을 대상으로 개 인환경 적합성과 조직 매력성, 몰입 및 직무 만족 간의 영향관 계를 분석함으로써 개인과 조직 환경의 상호작용 관점에서 조 직에 대한 관심과 몰입, 직무에 대한 만족도를 높일 수 있는
방안을 수립하고, 급변하는 시장 환경 속에서 TV 홈쇼핑업체의 인재 관리에 도움이 되는 자료를 제공하고자 하였다. 본 연구의 결과를 요약하면, 첫째, TV 홈쇼핑업체에서 개인환경 적합성은 개인-직무, 개인-상사 및 개인-조직 적합성으로 분류되었고, 이중 에서 개인-직무 적합성의 설명력이 가장 높게 나타났다. 둘째, 개 인환경 적합성을 구성하는 모든 요인이 조직 매력성 및 몰입에 영향을 미쳤으며, 특히 개인-직무 적합성의 영향력이 가장 높게 나타나 개인의 직무가 자신의 흥미나 관심, 적성 등에 적합할 수록 직장에 대해 더욱 관심을 가지고 몰입하고 있었다. 셋째, 직무 만족에는 조직 매력성과 조직 몰입이 영향을 주고 있었으 며, 조직 몰입에 비해 조직 매력성의 영향력이 더 크게 나타나 $\mathrm{TV}$ 홈쇼핑업체에서 직원들의 직무 만족을 유도하기 위해서는 직장에 대한 관심과 애착을 이끌거나 몰입할 수 있는 요소를 제공해야 할 필요성이 제기되었다. 이러한 결과에 근거하여 연 구의 의의 및 시사점을 제언하면 다음과 같다.

첫째, 개인-환경 적합성에 관한 기존의 연구에서는 공기업이 나 대기업, 스포츠 조직 등을 실증 분석하여 개인과 조직 환경 과의 상호작용 관계를 밝힌데 비해, 본 연구는 소비자를 대상 으로 상품을 판매하는 유통업에서 주요 부분으로 성장하고 있 는 TV 홈쇼핑업체를 대상으로 연구를 수행하였다. 또한 TV 홈 쇼핑업체에서 패션사업부 직원들의 조직에 대한 관심과 호감, 몰입 및 직무 만족에 영향을 미치는 개인-환경 적합성을 다차 원적인 측면에서 분석함으로써 패션분야의 연구에 적용할 수 있는 이론적 근거를 제시하고, 홈쇼핑업체에서 직장에 관심과 애착을 가진 인재를 유지, 관리할 수 있는 요소를 제공한 것에 의의가 있다.

둘째, TV 홈쇼핑업체에서 직원들의 직장에 대한 관심과 몰 입을 유도하여 효율적으로 조직을 운영하기 위해서는 개인과 직무, 개인과 상사, 개인과 조직 간의 적합도를 증가시킬 수 있 는 방안 수립이 요구된다. 예를 들어, 개개인의 적성과 관심사, 가치관 등을 파악하여 적재적소에서 일을 할 수 있도록 인사 
관리를 하고, 회사에서 추구하는 가치나 경영철학, 목표 등이 개인의 특성과 부합하는 지를 잘 살펴보아야 하며, 상사는 성 격과 가치관은 물론 추구목표나 일처리 방식 등에서의 일치 정 도를 고려하여 부하직원을 관리해야 할 것이다. 이와 함께 $\mathrm{TV}$ 홈쇼핑업체에서는 자사에 요구되는 인재를 확보하기 위해 어떠 한 보상요소를 제공할 것인지에 대한 가치제안을 명확히 설정 하고, 직원들의 특성에 따라 다르게 나타나는 요구를 기반으로 하여 보상의 효과 증대 및 경쟁사와 차별화된 보상 프로그램을 제공하도록 노력해야 할 것이다.

셋째, 패션 및 유통 기업 환경에서 인적 경쟁력의 중요성이 증가하고 있는 시점에 창의적이고 혁신적인 인재를 영입하거나 관리하기 위해서는 조직의 가치와 목표, 성격 및 철학 등과 부 합하는 인재를 선발하고, 이들이 실제 직무를 하면서 자신의 능 력을 최대한 발휘할 수 있도록 관리해야 한다. 특히 방송과 유 통의 결합으로 급변하는 패션 소비자의 옥구를 충족시키기 위 해서는 고객과의 커뮤니케이션이 중요하고, 고객의 변화에 따 라 각 업무가 신속하게 수행되어야 하는 TV 홈쇼핑업체의 특 성상 개인과 직무 혹은 개인과 상사와의 적합성 정도에 따라 성과가 달라질 수 있다. 그러므로 상사의 역할 및 역량을 강화 하여 부하직원들을 관리할 수 있는 조직 시스템을 운영하고, 직 원들이 업무에 헌신하고 노력할 수 있는 동기를 부여함과 동시 에 개인과 조직 환경과의 적합성을 고려하여 인력을 관리한다 면 인적 경쟁력을 높일 수 있을 것이다.

넷째, 본 연구의 결과에 의하면 $\mathrm{TV}$ 홈쇼핑업체에서 개인과 환경과의 적합성은 조직 매력성 및 몰입을 거쳐 직무 만족도를 높이는 요소인 것으로 나타났다. 따라서 직원들 개개인의 직무 만족도를 높이기 위해서는 자신의 직무나 상사, 조직과의 적합 성을 인식하도록 만드는 것이 중요하다. 뿐만 아니라 직원들의 직무 만족은 성과와 직접적인 연관이 있기 때문에 직장에 대한 관심과 애착, 몰입을 유도할 수 있는 요소를 제공함으로써 현 재 수행하는 업무에 보람을 느끼고 만족하도록 만들어야 할 것 이다. 예컨대, 창의성과 조화, 협동을 강조하고 직원들의 제안 이나 의견을 적극적으로 반영하며, 직원들의 역량을 키우는데 많은 노력을 기울인다면 개인과 조직 간의 상호작용이 높아져 즐겁게 일할 수 있는 조직이 될 것이다.

본 연구는 서울 소재의 TV 홈쇼핑업체로 한정하여 설문조 사를 실시하였기 때문에 연구 결과를 전체 패션 유통업체로 확 대해석할 수 없고, 조직 매력성과 몰입 및 직무 만족의 영향요 인으로 개인-환경 적합성만을 고려하였다는 한계를 가지고 있 다. 이 외에도 $\mathrm{CEO}$ 의 리더십이나 윤리적인 풍토, 조직문화 등 을 연구하거나 개인 환경 적합성이 영향을 줄 수 있는 직업변 경의도 및 조직변경의도 등의 연구가 요구되며, TV 홈쇼핑업 체만이 아니라 백화점, 대형 할인점, 인터넷 유통업체 등으로 구분하여 비교 연구하거나 패션 제조업체를 대상으로 연구를 실시한다면 산업적, 학문적으로 보다 심도 깊게 제언할 수 있 을 것이다.

\section{참고문헌}

김경수, 김공수. (1998). 개인과 조직의 일치: 인턴사원 제도가 조직 구성원의 사회화에 작업결과에 미치는 효과. 경영학연구, 27(4), 1003-1024.

김태희, 장경로. (2007). 스포츠센터 강사들의 개인-조직 적합성과 개 인-직무 적합성이 조직변경의도와 직업변경의도에 미치는 영향. 체육과학연구, 18(4), 197-207.

박양규. (1999). 상사와 부하간 리더쉽 행동특성의 적합성과 조직 유 효성에 대한 효과. 조직과 인사관리연구, 23(1), 145-161.

박원우, 고수경. (2006). 개인-조직 적합성과 직무태도 간 관계에서 프로세스 갈등의 매개역할. 경영학연구, 35(2), 521-555.

성지영, 박원우, 윤석화. (2008). 개인-환경(조직, 상사, 동료) 적합성 이 조직시민행동 및 개인성과에 미치는 영향과 공정성의 매개효 과 검증. 인사.조직연구, $16(2), 1-62$.

신유형. (2008). 팀 수준 개인-조직 및 개인-직무 적합성이 팀 수준 조직시민행동과 팀 효능감에 미치는 영향. 인사.조직연구, $16(1)$, 1-35.

양혁승, 정영철. (2002). 개인가치와 개인이 지각하는 조직가치가 개 인의 태도에 미치는 영향. 인사.조직연구, 10(2), 211-238.

오인수, 김광현, 황종오, 유태용, 박영아, 박량희. (2007). 직무만족, 조직몰입, 성과, 이직의도 간의 관련성 - 문헌고찰 및 메타분석. 인사.조직연구, 15(4), 43-86.

유태용, 현희정. (2003). 개인과 환경간 부합 연구에서 다차항 회귀분 석과 반응 표면 방법론의 적용. 한국심리학회지, 16(2), 1-19.

전타식. (2008). 제품유형에 따른 $T V$ 홈쇼핑 쇼 호스트의 신뢰성이 소 비자 반응에 미치는 영향. 인천대학교 대학원 박사학위논문.

정인희, 박경옥, 이미점, 민경선, 강진구. (2005). 패션 판매원의 직무 적합성에 관한 연구. 유통연구, $10(2), 73-97$.

정진철, 박현정, 김성만. (2007). 조직, 직무, 상사와의 적합성이 조직 매력성 지각을 통해 선제적 행동을 유발시키는 관계성에 관한 연구. 한국인사관리학회하계통합학술대회 논문집, pp. 1-24.

정효선, 윤혜현. (2009). 호텔 기업의 윤리 경영이 종사원의 개인조 직적합성, 직무만족도, 이직의도 및 조직성과에 미치는 영향에 관한 연구. 호텔경영학연구, $18(1), 59-83$.

최명옥, 유태용. (2005). 개인-조직, 개인-직무, 개인-상사 부합이 조 직몰입, 직무만족, 이직의도에 미치는 영향 : 부합들간의 상호작 용 효과를 중심으로. 한국심리학회지, 18(1), 139-162.

최수일, 이은진. (2009). 패션기업 팀장의 리더십과 팀원의 신뢰가 직 무몰입 및 만족에 미치는 영향. 한국의류산업학회지, $11(3), 399-$ 408.

한계숙, 이서구. (2009). 개인-조직환경 적합성과 탈진의 대상차원, 그 리고 성과간의 구조적 관계. 소비자학연구, 20(2), 121-147.

허명숙, 천면중. (2009). 조직 구성원의 개인환경 적합성과 정보시스 템 수용요인이 성과에 미치는 영향에 관한 연구: 사회자본의 매 개역할. Asia Pacific Journal of Information Systems, 19(2), $1-42$.

Bauer, T. N., \& Green, S. G. (1996). Development of leader-member exchange: A longitudinal test. Academy of Management Journal, 39(6), 1538-1568.

Bretz, E. L. (1969). Need-reinforcer correspondence as a predictor of job satisfaction. Personnel and Guidance Journal, 47(9), 878-883.

Carless, S. A. (2005). Person-job fit versus person-organization fit as predictors of organizational attraction and job acceptance intentions: A longitudinal study. Journal of Occupational and Organizational Psychology, 78(3), 411-429. 
Chatman, J. A. (1989). Improving interactional organizational research: A model of person-organization fit. Academy of Management Review, 14(3), 333-349.

Dawis, R. V., \& Lofquist, L. H. (1984). A psychological theory of work adjustment. Minneapolis: University of Minnesota Press.

Edwards, J. R. (1991). Person-job fit: A conceptual integration, literature review, and methodological critique. International Review of industrial and Organizational Psychology, 6, 283-357.

Harris, S. G., \& Mossholder, K. W. (1996). The affective implications of perceived congruence with cultural dimensions during organization transformation. Journal of Management, 22(4), 527547.

Kemelgor, B. H. (1982). Job satisfaction as mediated by the value congruity of supervisors and their subordinates. Journal of Occupational Behavior, 3(2), 147-160.

Kristof-Brown, A. L., Zimmerman, R. D., \& Johnson, E. C. (2005). Consequence of individuals's fit at work: A meta analysis of person-job, person- organizations, person-group, and personsupervisor fit. Personnel Psychology, 58(2), 281-342.

Lauver, K. J., \& Kristof-Brown, A. L. (2001). Distinguishing between employee's perceptions of person-job and person-organization fit. Journal of Vocational Behavior, 59(3), 454-470.

Lewin, K. (1951). A Dynamic theory of personality. New-York: McGraw-Hill.

Lyons, T. (1971). Role clarity, need for clarity, satisfaction tension, and withdrawal. Organizational Behavior and Human Performance, 6(1), 99-110.

Meglino, B. O., Ravlin, E. C., \& Adkins, C. L. (1992). The measurement of work value congruence: A field study comparison. Journal of Management, 18(1), 33-43.

Meir, E. I., \& Melamed, S. (1986). The accumulation of personenvironment congruences and well-being. Journal of Occupational Behavior, 7(2), 315-323.

Oleski, D., \& Subich, L. M. (1996). Congruence and career change in employed adults. Journal of Vocational Behavior, 49(3), 221-229.
O'Reilly, C. A., Chatmen, J., \& Caldwell, D. F. (1991). People and organizational culture: A profile comparison approach to assessing person-organization fit. Academy of Management Journal, 34(3), 487-516.

Saks, A. M., \& Ashforth, B. E. (1997). A longitudinal investigation of the relationships between job information sources, applicant perceptions of fit, and work outcomes. Personnel Psychology, 50(4), 395-426.

Schneider, B. (1987). The people make the place. Personnel Psychology, 40(3), 437-453.

Schneider, B., Goldstein, H. W., \& Smith, D. (1995). The ASA framework: An update. Personal Psychology, 48(4), 747-773.

Sims, R. L., \& Keon, T. L. (1997). Ethical work climate as a factor in the development of person-organization fit. Journal of Business Ethics, 16(11), 1095-1105.

Smidts, A., Pruyn, A., \& Van Riel, C. (2001). The impact of employee communication and perceived external prestige on organizational identification. Academy of Management Journal, 44(5), 10511062.

Smith, M. A. (2002). Subordinate-supervisor "fit" using the big five personality constructs. Paper presented at the 17th annual conference of the Society of Industrial and Organizational Psychology. Toronto, Canada.

Turban, D. B., \& Greening, D. W. (1996). Corporate social performance and organizational attractiveness to prospective employers. Academy of Management Journal, 40(3), 658-672.

Van Vianen, A. E. M. (2000). Person-organization fit: The match between newcomers' and recruiters' perceptions for organizational cultures. Personnel Psychology, 53(1), 113-149.

Verquer, M. L., Beehr, T. A., \& Wagner, S. W. (2003). A meta-analysis of relations between person-organization fit and work attitudes. Journal of Vocational Behavior, 63(3), 473-489.

(2010년 7월 6일 접수/ 2010년 8월 13일 1차 수정/2010년 8월 13일 게재확정) 